NBER WORKING PAPER SERIES

BELTS AND SUSPENDERS:

INTERACTIONS AMONG CLIMATE POLICY REGULATIONS

\author{
Arik Levinson \\ Working Paper 16109 \\ http://www.nber.org/papers/w16109 \\ NATIONAL BUREAU OF ECONOMIC RESEARCH \\ 1050 Massachusetts Avenue \\ Cambridge, MA 02138 \\ June 2010
}

Gilbert Metcalf, Don Fullerton, and participants at the May 13-14 Conference on "The Design and Implementation of U.S. Climate Policy" provided helpful feedback on an early draft. The views expressed herein are those of the author and do not necessarily reflect the views of the National Bureau of Economic Research.

NBER working papers are circulated for discussion and comment purposes. They have not been peerreviewed or been subject to the review by the NBER Board of Directors that accompanies official NBER publications.

(C) 2010 by Arik Levinson. All rights reserved. Short sections of text, not to exceed two paragraphs, may be quoted without explicit permission provided that full credit, including $\odot$ notice, is given to the source. 
Belts and Suspenders: Interactions Among Climate Policy Regulations

Arik Levinson

NBER Working Paper No. 16109

June 2010

JEL No. Q58

\begin{abstract}
$\underline{\text { ABSTRACT }}$
With few exceptions, economic analyses of "cap-and-trade" permit trading mechanisms for climate change mitigation have been based on first-best scenarios without pre-existing distortions or regulations. The reason is obvious: interactions between permit trading and other regulations will be complex. However, climate policy proposed for the U.S. will certainly interact with existing laws, and will also likely include additional regulatory changes with their own sets of interactions. Major bills introduced in the U.S. Congress have included both permit trading and traditional command and control regulations - a combination sometimes called "belts and suspenders." This paper discusses interactions between these instruments, and begins to lay out a framework for thinking about them systematically. The most important determinant of how the two types of instruments interact involves whether or not the cap-and-trade permit price would induce more or less abatement than mandated by the traditional standards alone. Moreover, economists' experience predicting the costs of environmental regulations suggests we are more likely to overestimate the costs of cap-and-trade, and therefore the price of carbon permits, than we are to overestimate the costs of a traditional regulatory standard, and that therefore the regulatory standards will likely reduce the cost-effectiveness benefits of cap-and-trade.
\end{abstract}

Arik Levinson

Department of Economics ICC 571

Georgetown University

3700 O St., NW

Washington, DC 20057

and NBER

aml6@georgetown.edu 


\section{Belts and Suspenders: Interactions Among Climate Policy Regulations}

\section{Introduction}

Climate policy, if it is to be successful, will be large. Aldy and Pizer (2008) put the cost to the U.S. as comparable to the "total cost of all existing environmental regulation." Unfortunately, economists' models work best at the margins, predicting the consequences of small incremental changes in policy affecting isolated sectors of the economy. Models work less well for large discrete shifts in policy affecting many sectors simultaneously, the type of regulation likely to be necessary to reduce greenhouse gas (GHG) emissions. The difficulty inherent in assessing large policy changes is that their general equilibrium effects can be vast - even bigger than their direct effects.

Another word for general equilibrium effects, broadly speaking, is "interactions." The size and scope of proposed climate legislation means there will be important interactions with most of the economy, including government tax revenues, other environmental problems aside from climate change, labor markets, terms of trade effects, and other government regulations.

To define a reasonably limited area of attention, I focus on the simplest and most direct form of interaction - those between the tradable GHG emissions permit systems ("cap and trade") that are part of many proposed and enacted new climate bills around the world, and the more traditional command-andcontrol regulatory standards. For climate regulations that have already been passed, mostly in Europe, and for the climate regulations that have been proposed in the U.S., the coexistence of these multiple instruments is "the norm, rather than the exception" (Bennear and Stavins, 2007). In part, that coexistence has emerged because the cap-and-trade climate laws have been laid down on top of decades of traditional standards. But the coexistence is also written into the language of climate bills that typically include both tradable permits and traditional standards. Either way, we need to think about interactions between the two types of regulatory instruments.

The coupling of tradable permits with traditional standards has been called a "belt-andsuspenders" approach (Pearlstein 2009). In this case, however, it is not clear whether the belt and 
suspenders are mutually reinforcing, redundant but harmless, or working at cross-purposes. All three viewpoints have appeared in print. Krugman (2010) articulates the mutually reinforcing viewpoint: "I would advocate supplementing market-based disincentives with direct controls." Sijm (2005) makes the case for redundancy: "the coexistence of [tradable permits] and policies affecting fossil fuel use by participating sectors is hard to justify and, hence, these policies could be considered to be redundant and ready to be abolished." And the U.S. Congressional Budget Office (2009) sees the two as sometimes conflicting: "regulatory standards combined with market-based approaches often will increase the cost of meeting an environmental goal."

Which viewpoint is correct? The answer can be seen in a simple reinterpretation of the textbook partial-equilibrium model illustrating the cost-effectiveness of tradable permit schemes. And that answer depends on whether the price of the tradable GHG emissions permits, and hence the marginal cost of compliance with the cap-and-trade legislation, is higher or lower than the marginal cost of compliance with the traditional regulatory standard. Intuitively, if the permit price exceeds a firm's regulatory compliance costs, that firm would abate beyond the regulatory standard anyway, in response to the capand-trade incentives, and the regulatory standard would be irrelevant for that firm. By contrast, if the permit price falls below the regulatory compliance costs for a firm, the firm would meet the regulatory standard exactly and either sell excess permits or buy fewer than it would under cap-and-trade alone. The regulatory standard raises the firm's cost of abating emissions without any resulting increase in overall abatement. Are there economic reasons to pair a tradable permit system with traditional regulatory standards? If there are other market failures aside from the GHG externality, or there are administrative complications in directly targeting GHG emissions, then there may be rationales for combining the two policies, though here we must be careful not to extrapolate from logic that applies to local pollutants but not to greenhouse gases. And finally, economists' demonstrated experience forecasting regulatory costs suggest we are more likely to overstate the costs of meeting a cap-and-trade regulation than a traditional standard, and that therefore where the two instruments are paired, they are likely to increase costs without accompanying abatement benefits. 
Before turning to focus on interactions between cap-and-trade and traditional standards, it is worth recognizing a few of the many important interactions the simple textbook model omits.

\section{Other Interactions -- An Aside}

U.S. climate policy will interact with a long list of other important considerations. For example, analysts have long recognized that policies aimed at reducing one pollutant may result in more or less emissions of another (Sigman, 1996). For another, an enormous literature exists on spillover effects across countries, either because environmental regulations in one country move polluting industry to less stringent countries (Brunnermeier et al., 2004), or because, more subtly, environmental regulations have terms of trade effects (Bohringer et al., 2010). Another vast literature looks interactions between pollution taxes and other government taxes (Goulder, 2002) and expenditures (Metcalf, 2008).

The focus here, broadly speaking, is about how environmental regulations targeted at the same pollutant interact with one another. Economists have begun to recognize the importance of these interactions, as policies have begun to pile up and interact in complex ways (Oikonomou and Jepma, 2008; Sorrel and Sijm, 2003; Either and Pethig, 2009). This work tends to provide semantic taxonomies of interactions, elaborate charts of interactions, or models with features designed to study specific but very complex parts of the EU's existing tradable permit system. And, to my knowledge, there has been no empirical work that would shed light on the extent of the possible interactions or their consequent effects.

\section{The Textbook Model}

For a long time, economists have focused on persuading policymakers to use market-based instruments - emissions taxes or cap-and-trade - instead of traditional regulatory standards rather than in addition to traditional standards. Some version of figure 1 appears in most undergraduate environmental economics texts, as a means of illustrating the cost-effectiveness of a tradable permit system compared with a regulatory standard. The bottom axis displays the total uncontrolled pollution from two sources. The sources could be two factories, two industries, two different control strategies, etc. Source one, for 
example, could be carbon mitigation from utilities using renewable energy portfolios, and source 2 could represent carbon mitigation from increased energy efficiency. Each source has a marginal abatement cost curve (MAC). Regulatory standards mandate a certain amount of abatement from each source. Figure 1 depicts two such standards, where the standard imposed on source $1\left(\operatorname{Std}_{1}\right)$ leads to lower marginal abatement costs than the standard imposed on source $2\left(\operatorname{Std}_{2}\right)$. The point of tradable permits is to allow source 1 to do more abatement and source 2 to do less abatement, until the MACs are equal (to $\mathbf{P}^{*}$ ) and no further gains are possible. The cost savings are areas $\boldsymbol{c}+\boldsymbol{d}-\boldsymbol{b}$, or equivalently the shaded areas $\boldsymbol{a}+\boldsymbol{c}$. These cost savings provide the justification for replacing standards with tradable permits.

In practice, however, US climate legislation will likely contain a tradable permit scheme along with regulatory standards, either because the standards predate the newer tradable permit scheme, or because the new legislation has both parts. For example, Title III of H.R. 2454, the bill the U.S. House of Representatives passed in 2009, would impose a tradable cap on GHG emissions, while Title I of the same bill requires electric utilities to generate up to 25 percent of their output from renewable sources.

First suppose that the standards on the two sources, "Std 1 " and "Std 2 " in figure 1, are designed to achieve the same total abatement as the permit system acting alone, where the permit-only policy would result in the permit price $\mathbf{P}^{*}$. Initially, suppose that $\operatorname{Std}_{1}$ is in effect, that source 2 faces no standard, and that the permit policy is added on top of the single standard $\operatorname{Std}_{1}-\mathrm{a}$ belt and suspenders approach. In this case, the marginal cost to source 1 of meeting $\operatorname{Std}_{1}$ is $\mathbf{P}^{\prime}$, which is less than the permit price $\mathbf{P}^{*}$. For source 1 , the regulatory standard is effectively irrelevant. Polluters in this situation would choose to do more abatement than required by the standard, even if the standard did not exist. There may be some regulatory costs associated with administering the standard (monitoring, compliance paperwork, etc.), but other than that, the standard has no economic costs.

On the other hand, suppose the single standard is like " $\operatorname{Std}_{2}$ " in figure 1, combined with the same permit policy with price $\mathbf{P} *$. Here the marginal cost of meeting the standard exceeds the marginal costs of meeting the tradable emissions cap. By forcing more abatement via source 2, $\operatorname{Std}_{2}$ standard lowers the market price of the tradable permits from $\mathbf{P}^{*}$ to $\mathbf{P}^{\prime}$, reducing the incentive for polluters to abate via source 
1 (down to the same level as if they had faced only $\operatorname{Std}_{1}$ ). In this simple two-source model, the efficiency costs from combining standard 2 with a cap-and-trade permit policy - belts and suspenders - are the shaded areas, $\boldsymbol{a}+\boldsymbol{c}$, the same as the total efficiency cost of imposing both standards with no tradable permits. The cost savings from the tradable permit scheme are eliminated by the imposition of standard 2 alone. ${ }^{1}$

Setting aside for a moment the possibility that the standard and permit schemes are mutually reinforcing in some way not described by figure 1, how can we tell if the standard is irrelevant like standard 1, or costly like standard 2? The key distinction is whether the marginal compliance costs for meeting the standard are lower or higher than the cap-and-trade permit price. If the costs from the standard are lower, the standard is largely irrelevant; if the costs from the standard are higher, it imposes real costs.

The CBO (2009) estimates that the renewable portfolio standards in Title I of H.R.2454 are like standard 1 in figure 1 - largely irrelevant economically because the estimated cost of meeting the standard will fall short of the estimated tradable GHG emissions permit price. By contrast, Abrell and Weight (2008) examine the European Union's Emissions Trading System, in conjunction with the renewable portfolio standards in Germany. They find the German renewable portfolio standard to be much more costly than the price of GHG permits, and that the renewable standards push the carbon price to zero. In other words, all of the abatement necessary will come from the one source - renewables, despite the fact that other sources are less costly. ${ }^{2}$

This finding is typical. Fullerton et al. (1997) find that forcing electric utilities to abate carbon with scrubbers, rather than by purchasing sulfur dioxide (SO2) emission permits, increases abatement costs by a multiple of five. Gonzalez (2007) surveys a number of papers that examine this tradeoff

\footnotetext{
${ }^{1}$ Fischer and Preonas (2010) formalize this line of reasoning where a tradable permit system interacts with policies promoting renewable sources of electricity.

${ }^{2}$ In fact, if Abrell and Weight are correct, the cost-inefficiency of Germany's renewable portfolio may have a silver lining. The standards would lead to an excess supply of permits, meaning that they reduce GHG emissions by more than the total required by the carbon cap. In other words, renewables alone as a source of abatement reduce GHG by more than would be reduced by all sources combined under the tradable cap.
} 
between tradable emissions permits and renewable electricity standards. The studies he examines find that the coexistence of the two instruments is generally costly, because renewable electricity sources are not typically the least-cost means of abating GHG emissions. For example, Unger and Ahlgren (2005) examine tradable GHG permits for the Nordic countries, and find that a renewable electricity standard of 10 percent reduces carbon emissions at a cost seven times higher than a pure cap-and-trade system.

All of these studies make predictions about whether the non-market regulations will be inframarginal, inducing less compliance than predicted by response to cap and trade, or binding, inducing more compliance. This turns out to be a tricky forecast, because the whole rationale for cap-and-trade is that compliance costs are difficult to predict. In fact, Harrington, et al. (2000) compare ex ante and ex post assessments of U.S. regulations issued by EPA and OSHA, and find that the ex ante forecasts of costs are typically too high.

"Of the rules initially examined, 14 projected inflated total costs, while pre-regulation estimates were too low for only 3 rules. These exaggerated adjustment costs are often attributable to underestimates of the potential that technological change could minimize pollution abatement costs."

Moreover, the largest overestimates occurred in the case of the market-based policies - taxes and tradable permit schemes, which makes sense because those rules leave polluters the most scope for flexible technological responses. This in turn means that we are more likely to overestimate the costs of a capand-trade component of any new climate bill, and less likely to overestimate the costs of any preexisting or accompanying traditional regulatory standards, leaving those standards more likely to interact badly with the permit trading mechanism, reducing its cost effectiveness. Even if we predict that the renewable portfolio standards will be inframarginal, as the CBO (2009) predicts for the renewable portfolio standards in Title I of HR 2434, experience suggests that prediction is likely to overstate the carbon permit prices relative to renewable portfolio standards, and therefore to understate the degree to which the cost-effectiveness of carbon trading is undermined.

In an important sense, the problem here is worse than the usual comparison between standards and tradable permits. In the standard case, highlighted famously in a table in Tietenberg (1990) 
documenting the efficiency gains from moving to a market-based policy, there is a hidden benefit of traditional regulatory standards. Under standards, some sources of pollution over-abate. For example, Atkinson and Lewis's (1974) study of particulates in St. Louis found that a market-based system that equated marginal abatement costs would meet the ambient standards at only one-sixth the cost of existing regulatory standards. But Oates et al, (1989) point out that one of the reasons the regulatory standard's costs are high is that they over-regulate some sources in order to meet the ambient pollution standard everywhere. An ideally-designed market-based system would just meet the constraint at every locale, and hence yield more pollution in some places than would the non-market standard. If we take into account the net benefits of the market-based standard (net of those excess abatement benefits), the difference between market-based and non-market regulations is smaller. The key, however, to the Oates et al. result is the spatial heterogeneity of pollution. By imposing the same regulatory standard on all locations, some areas inevitably exceed the local ambient standard. A market-based solution that allows over-complying areas to sell emissions permits until they just meet the local ambient pollution standard would comply with the regulation at lower cost, but impose some new environmental costs on those permit-selling regions. Oates et al. account for that loss of environmental quality when they tally up the net benefits of market based policies.

For greenhouse gases, however, there would be no such net adjustment, because there are no geographic differences, or "hot spots" in climate change. If a regulatory standard induces over-abatement by once source, that depresses the permit price for all sources, reducing abatement by other sources so as to completely offset the over-abatement in the first place. In the Oates et al. example, the regulatory standard reduces pollution in some locales, without a corresponding increase elsewhere, because all regions must meet the minimum ambient standard. With greenhouse gases, permit trading allows reduced emissions in some locales or by some sources to be completely offset by increased emissions elsewhere. The silver lining of non-market policies described by Oates et al. does not apply in the case of this global pollutant. 


\section{Rationales for Multiple Policies: Other Market Failures and Administrative Complexity}

Figure 1 and the accompanying text describe two possible results of interacting tradable permit schemes and traditional regulatory standards: the standards could be irrelevant, or they could increase compliance costs with no associated benefits. But there is a third possibility. There could be an economically sound rationale for enacting a tradable permit regulation in combination with a traditional regulatory standard - the belt and suspenders combination could work better than either policy alone. These rationales fall into two broad categories: (1) other market failures, and (2) administrative complexity. While these rationales have been used to justify combining permits and traditional regulations for local air pollutants, such as the criteria air pollutants that have been regulated by the Clean Air Act since the 1970s, not all of the rationales turn out to be applicable to greenhouse gases and global climate change.

Start with the first category: "other market failures." The main market failure is, of course, the pollution externality. GHG emitters do not take into account damages they may impose on others or on future generations. That, however, is unlikely to be the only departure from perfectly competitive assumptions relating to GHG emissions. One additional market failure involves research and development (R\&D) in new GHG-abating technologies. If one firm invests in R\&D and invents a new abatement technology, or a new energy efficiency technology that by coincidence abates GHG emissions, some benefits from that invention spill over to other firms, because they either imitate the technology or build upon it with further R\&D. Consequently, firms will likely underinvest in $R \& D$, relative to what would be optimal. Jaffe et al. (2005) nicely summarize the interactions between these two market failures: "Pollution creates a negative externality, and so the invisible hand allows too much of it. Technology creates positive externalities, and so the invisible hand produces too little of it."

In theory, however, $\mathrm{R} \& \mathrm{D}$ market failures can work in the opposite direction, and lead to overinvestment relative to the optimum. Competitive firms may duplicate each other's R\&D efforts, resulting in wasteful investment by some firms. Similarly, firms may invest in rent-seeking R\&D aimed at slight innovations that would replacing existing technologies with new ones that are only marginally 
better, but would capture market rents. ${ }^{3}$ On balance, empirical studies find that the industry-wide return to $R \& D$ is approximately two to four times as high as the returns to any one firm, suggesting underinvestment in R\&D (Jones and Williams, 1998).

To correct this underinvestment in $\mathrm{R} \& \mathrm{D}$, we might consider pairing a tradable permit scheme to address the first market failure with an R\&D subsidy to address the second, where the R\&D subsidy induces GHG abatements like one of the two regulatory standards in figure 1. However, unless there is something else at work here, nothing about the $R \& D$ market failure is particular to the environment, and there is no reason a sensible R\&D policy shouldn't be economy-wide, rather than targeted at GHGreducing technologies.

In fact, however, there are other factors at work that may justify targeting R\&D subsidies at GHG technologies. One such justification involves the seeming insensitivity of consumers and businesses to energy price signals. Hausman (1979) showed that implausibly high discount rates would be needed to justify the choices consumers were making among room air conditioners with varying energy efficiency and prices. This "energy paradox" has been documented many times since then, and has been explained in various ways. Levinson and Niemann (2004) note that for apartment tenants, either the landlords pay for the utility bills and tenants therefore have no incentive to conserve energy on a daily basis, or tenants pay for the utility bills and landlords therefore have no incentive to invest in energy-efficient appliances or construction. Any price signals from a tradable permit system would be weakened because either tenants or landlords do not face the true marginal cost of their energy decisions. This might provide a justification for combining a tradable permit policy with an R\&D subsidy targeted at energy efficiency. ${ }^{4}$ But more likely, it justifies pairing tradable permits with energy efficiency standards and building codes

\footnotetext{
${ }^{3}$ Jones and Williams (1998) name this spillover aspect of R\&D the "standing on shoulders" effect, and the socially wasteful duplication the "stepping on toes" effect.

${ }^{4}$ Another explanation for the energy paradox comes from Hassett and Metcalf (1993), who point out that energy prices are uncertain, but that energy saving investments are irreversible, leading to rational unwillingness to invest. In that case there is no "other market failure," and no economic rationale for a second policy instrument.
} 
for appliances and construction. ${ }^{5}$ Either way, some form of regulatory standard could complement a GHG emissions permit system. ${ }^{6}$

The second broad rationale for pairing traditional regulatory standards with tradable permit schemes involves administrative complexity - difficulty attaching a market price to emissions. One such source of complexity that has been used to justify pairing tradable permits with regulatory standards in analogous contexts, but which would not apply to GHG emissions, involves the spatial heterogeneity of damages. Unlike GHGs, the damages from most pollutants vary depending on where they are emitted. This makes organizing and administering a tradable permit scheme difficult. One could imagine, for example, a matrix of pollution transfer coefficients mapping pollution from each location of emission and to each location of deposition (McGartland and Oates, 1985). To avoid this, designers of the U.S. SO2 trading program intentionally simplified the system. One ton of $\mathrm{SO} 2$ is treated the same whether it is emitted in the Midwest and falls on New England, or emitted on the Atlantic coast and drifts out to sea.. This spatial heterogeneity means that locations with high abatement cost s risk becoming large net purchasers of $\mathrm{SO} 2$ emissions permits and emitters of $\mathrm{SO} 2$, and therefore having high ambient $\mathrm{SO} 2$ concentrations. Some states responded to this by enacting command-and-control regulations on top of the $\mathrm{SO} 2$ trading program, or by prohibiting trades. Wisconsin prevented some local utilities from buying SO2 permits, and Illinois mandated scrubber installation (Johnstone, 2003). These constraints, coupling tradable permit and traditional regulations, can be seen as a costly response to the complexity of regulating heterogeneous sources. But they are not relevant to GHG emissions because their justification is based on eliminating hot spots of excess pollution, and for climate change no such heterogeneity of damages exists.

A second "complexity" justification involves uncertainty in predicted abatement costs. Since Weitzman (1974), economists have recognized that uncertainty in marginal pollution abatement costs

\footnotetext{
${ }^{5}$ Another might be product labeling, which has been shown to be effective in combination with energy price increases (Newell et al., 1998).

${ }^{6}$ Acemoglu et al. (2010) model this formally in an optimal growth model with endogenous technical change and an environmental externality. They show that the optimal policy can involve both a (dynamic) pollution tax and an R\&D subsidy directed at the polluting sector.
} 
means there is an important distinction between quantity regulations (cap-and-trade) and price regulations (pollution taxes). Cap-and-trade leads to certainty about the quantity of pollution, but uncertainty about the costs imposed on polluters. Pollution taxes yield certain costs, but uncertain pollution quantities. Roberts and Spence (1976) proposed pairing the two, so that a set amount of pollution permits are traded, but polluters can exceed their permitted quantities by paying a pollution tax. The tax puts a known ceiling on the otherwise uncertain permit price. One could also imagine a price floor where the government would agree to purchase all permits at some set price (Pizer, 2002). This type of price "collar" is contained in both the CLEAR Act proposed in 2009 by Senators Cantwell and Collins and the American Power Act proposed in 2010 by Senators Kerry and Lieberman.

These price collars, however, are not the type of multiple instrument setup imagined in figure 1, in that both the tradable permits and the price collar are related market-based instruments. Price collars are more accurately described as slightly more elaborate versions of tradable permit policies, a single instrument. Moreover, in several cases where the tradable permit schemes have included price caps, those caps have never been reached and were therefore irrelevant - much as a low-cost standard would be. The Danish CO2 trading mechanism had a price cap at 40 DKK/ton, which was never reached (Johnstone, 2003). Similarly, the US Acid Rain program set an initial SO2 permit price cap at $\$ 1500 /$ ton. Permit prices mostly traded between $\$ 100$ and $\$ 300$, and the price cap was scrapped. In both cases, it seems the existence of the price cap may have appeased worries about extremely high costs and eased passage of the legislation politically, but imposed no economic consequences.

A source of administrative complexity possibly more relevant to climate change involves difficulty monitoring emissions directly, a precondition for administering a tradable permit system. In developing countries where households collect and burn firewood for heat and cooking, administering a tradable permit system for the resulting GHG emissions seems improbable. For the U.S., however, where regulated markets already exist for the fuels consumers use for home energy, administering an upstream tradable permit system seems relatively straightforward. 
Another oft-cited example of monitoring difficulties involves automobile tailpipe emissions. For criteria pollutants, such as nitrogen oxides (NOx) and carbon monoxide (CO), tailpipe emissions depend on the nature of the gasoline, the characteristics of the vehicle, and the behavior of the driver. Regulating or permitting tailpipe emissions directly still seems technologically infeasible. And regulating gasoline, vehicle characteristics, or miles driven in isolation would miss the other components. (A gasoline tax provides no incentive to maintain emission control equipment.) The obvious solution is a combination of policies, such as the gasoline tax and new car subsidy studied by Fullerton and West $(2002,2010)$ or Walls and Palmer (2001). A key difference, however, between the criteria pollutants (NOx, CO, etc.) and greenhouse gases is that while criteria pollutant emissions depend on automobile and driver characteristics, GHG emissions depend almost exclusively on the carbon content of the fuel and how much is consumed. So a tradable permit system can be administered quite easily, upstream at the level of the fuel suppliers. ${ }^{7}$

Metcalf and Weisbach (2009) address this point directly. They examine the entire inventory of U.S. GHG emissions, and show that 80 percent of those emissions could be covered by a tax or permittrading policy governing only about 3000 taxed or regulated entities. The other 20 percent would have to be regulated with traditional standards. So long as polluters in that remaining 20 percent were not allowed to sell permits to the other 80 percent based on their compliance with those standards, there would be no interaction between the two policy instruments. Metcalf and Weisbach's analysis suggests that the administrative complexity argument used to justify combining tradable permits with traditional regulations for other air pollutants does not apply to GHG emissions in the United States.

In sum, these other market failures and sources of administrative complexity can in theory provide economic rationales for combining cap-and-trade with more traditional standards, but we must be careful. In many cases the rationales do not apply to the case of U.S. greenhouse gas emissions and climate change, because GHG damages do not depend on the location of emissions, and because GHC emissions are more directly related to the characteristics of fuels and can be effectively administered

\footnotetext{
${ }^{7}$ See Erin Mansur's chapter in this volume: "Upstream versus Downstream Implementation of Climate Policy".
} 
upstream of final users. The most consistent economic rationale for multiple instruments involves either (a) multiple market failures, as with the R\&D externality and the landlord/tenant energy paradox, or (b) administrative difficulty assigning permits to GHG emissions, as with nonpoint sources in developing countries. In other cases the rationale is not so clear, and we should ask whether the multiple-policy legislation enacted in Europe and proposed for the U.S. has an economic basis.

\section{Conclusion}

Climate policy in the U.S. is likely to combine tradable permits with more traditional regulatory standards. These standards have the potential to be harmlessly redundant, to reduce the cost-effectiveness of the tradable permits, or to solve a problem involving multiple market failures or administrative complexity. In the worst-case scenario, if polluters are allowed to sell permits based on their compliance with non-market regulations two things could happen. (1) The non-market, traditional regulatory portion of a climate bill could reduce the efficiency gains from the market-based tradable permit portion. And (2), the market-based, tradable permit parts of a climate bill could reduce the environmental gains from the traditional regulatory standards. The root cause of both is the same: polluters forced to meet a costly regulatory standard sell permits, reducing their price, and shrinking the market incentives for abatement from other sources.

To assess in advance whether the traditional regulatory components of new legislation are redundant or interact to reduce the cost effectiveness of the cap-and-trade components, we need to forecast the compliance costs of both components. But as Harrington et al. (2000) show, we are likely to overstate the compliance costs of cap-and-trade, relative to traditional regulations, and therefore to understate the degree to which the traditional regulations erode the cost-effectiveness of cap-and-trade.

If the non-market component of legislation has an economic rationale - a second market failure, or difficulty regulating the externality directly - then in a best-case scenario, polluters would not be allowed to sell emissions permits based on compliance with the non-market parts of the law. This is a legislative issue, but the economic rationale is that if polluters can meet their tradable caps by complying 
with the non-market regulation, that regulation is either irrelevant and a waste of administrative resources, or binding and damaging to the cost-effectiveness of the cap-and-trade permit system.

\section{References}

Abrell, Jan and Hannes Weigt. 2008. " The Interaction of Emissions Trading and Renewable Energy Promotion" Dresden University of Technology WP-EGW-05.

Acemoglu, Daron, Philippe Aghion, Leonardo Bursztyn and David Hemous. 2010. "The Environment and Directed Technical Change" NBER Working Paper 15451.

Aldy, Joseph, and William Pizer. 2008. "Issues in Designing U.S. Climate Change Policy" Resources for the Future DP 08-20.

A.H. Barnett. 1980. "The Pigouvian Tax Rule Under Monopoly" American Economic Review 70(5): 1037-1041.

Bennear, Lori Snyder and Robert N. Stavins. 2007. " Second-best theory and the use of multiple policy instruments" Environ Resource Econ 37:111-129.

Bohringer, Christoph, Henrike Koschel, and Ulf Moslener. 2008. "Efficiency Losses from Overlapping Regulation of EU Carbon Emissions" Journal of Regulatory Economics 33. pp.299-317.

Boehringer, Christoph, Carolyn Fischer, and Knut Einar Rosendahl . 2010. "The Global Effects of Subglobal Climate Policies"

Brunnermeier, Smita and Arik Levinson. 2004. "Examining the Evidence on Environmental Regulations and Industry Location" Journal of the Environment and Development 13(1): 6-41.

Congressional Budget Office (CBO). 2009. "How Regulatory Standards Can Affect a Cap-and-Trade Program for Greenhouse Gases" September 16, 2009.

Congressional Budget Office (CBO). 2009. "Cost Estimate for H.R. 2454 American Clean Energy and Security Act of 2009" June 5, 2009.

Egenhofer, C. 2002. "The Compatibility of the Kyoto Mechanisms with Traditional Environmental Instruments", in C. Carraro and C. Egenhofer (eds), Firms, Governments and Climate Policy: Incentive Based Policies for Longterm Climate Change, Cheltenham, Edward Elgar.

Eichner, Thomas, and Rudiger Pethig. 2009. "Efficient CO2 Emissions Control with Emissions Taxes and International Emissions Trading" European Economic Review 53. pp.625-635.

Fischer, Carolyn and Louis Preonas. 2010. "Combining Policies for Renewable Energy: Is the Whole Less than the Sum of Its Parts?" Resources for the Future DP 10-19.

Fullerton, Don, Shaun P. McDermott, and Jonathan P. Caulkins. 1997. "Sulfur Dioxide Compliance of a Regulated Utility" Journal of Environmental Economics and Management 34: 32-53. 
Fullerton, Don and Sarah West. 2010. "Tax and Subsidy Combinations for the Control of Car Pollution" The B.E. Journal of Economic Analysis \& Policy 10 (1): Iss. 1 (Advances), Article 8.

Fullerton, Don and Sarah West. 2002. "Can Taxes on Cars and Gasoline Mimic an Unavailable Tax on Emissions?" Journal of Environmental Economics and Management 42: 135-157.

Gonzalez, Pablo del R10 . 2007. " The interaction between emissions trading and renewable electricity support schemes: An overview of the literature" Mitigation and Adaptation Strategies for Global Change 12:1363-1390.

Goulder, Lawrence. 2002. Environmental Policy Making in Economies With Prior Tax Distortions. Edward Elgar.

Grubb, M. and Ulph, D. 2002. "Energy, Environment, and Innovation" Oxford Review of Economic Policy 18:92-106.

Harrington, Winston, Richard D. Morgenstern, and Peter Nelson. 2000. "On the Accuracy of Regulatory Cost Estimates" Journal of Policy Analysis and Management 19(2): 297-322.

Harrington, Winston, Richard D. Morgenstern, and Peter Nelson. 2010. "How Accurate are Regulatory Cost Estimates?" Resources for the Future.

Hassett, Kevin A. and Gilbert E. Metcalf. 1993. "Energy conservation investment: Do consumers discount the future correctly?" Energy Policy 21(6): 710-716.

Hausman, J. 1979. "Individual discount rates and the purchase and utilization of energy-using durables" Bell Journal of Economics 10: 33-54.

Jaffe, Adam, Richard Newell, and Robert Stavins. 2002. "Technological Change and the Environment" in Karl-Göran Mäler and Jeffrey Vincent, eds, Handbook of Environmental Economics. Amsterdam: North-Holland.

Jaffe, A. B., R. G. Newell, \& R.N. Stavins. 2005. "A Tale of Two Market Failures: Technology and Environmental Policy" Ecological Economics 54: 164-174.

Johnstone, Nick. 2002 "The Use of Tradable Permits in Combination with Other Policy Instruments" Working Party on National Environmental Policy, Document No. ENV/EPOC/WPNEP/(2002)28, Paris, Organization for Economic Cooperation and Development.

Johnstone, Nick. 2003. "Efficient and Effective Use of Tradeable Permits in Combination with Other Policy Instruments" Organization for Economic Cooperation and Development.

Jones, C. and J. C. Williams. 1998. "Measuring the Social Return to R\&D". Quarterly Journal of Economics pp. 1119-1135.

Kolstad, Charles D. 2011. Environmental Economics 2nd Edition. New York: Oxford University Press.

Konidari, Popi and Dimitrios Mavrakis. 2006. "Multi-Criteria Evaluation of Climate Policy Interactions" Journal of Multi-Criteria Decision Analysis 14: pp. 35-53.

Krugman, Paul. 2010. "Building a Green Economy" New York Times. April 10. 
Lehmann, Paul. 2008. "Using a Policy Mix for Pollution Control - A Review of Economic Literature" Helmholtz Centre for Environmental Research - UFZ Leipzig, MPRA Paper No. 21354.

Levinson, Arik and Scott Niemann. 2004. "Energy Use by Apartment Tenants when Landlords Pay for Utilities" Resource and Energy Economics, 26(1) 51-75.

Metcalf, Gilbert. 2008. "Using Tax Expenditures to Achieve Energy Policy Goals" American Economic Review Papers and Proceedings 98: 90-94.

Metcalf, Gilbert and David Weisbach. 2009. " The Design of a Carbon Tax" Harvard Environmental Law Review 33:499-556.

McGartland, Albert M. and Wallace E. Oates. 1985. "Marketable permits for the prevention of environmental deterioration" Journal of Environmental Economics and Management 12(3): 207228.

Oates, Wallace E., Paul R. Portney and Albert M. McGartland. 1989. "The Net Benefits of IncentiveBased Regulation: A Case Study of Environmental Standard Setting" American Economic Review 79(5): 1233-1242.

Oikonomou, V. and C. J. Jepma. 2008. " A framework on interactions of climate and energy policy instruments" Mitigation and Adaptation Strategies for Global Change 13:131-156.

Pearlstein, Steven. 2009. "Climate-Change Bill Hits Some of the Right Notes but Botches the Refrain" Washington Post. Friday, May 22.

Pizer, William A. 2002. "Combining price and quantity controls to mitigate global climate change" Journal of Public Economics 85(3): 409-434.

Roberts, Marc J. and Spence, Michael. 1976. "Effluent charges and licenses under uncertainty" Journal of Public Economics 5(3-4): 193-208.

Sigman, Hilary. 1996. "Cross-Media Pollution: Responses to Restrictions on Chlorinated Solvent Releases" Land Economics 72: 298-312.

Sijm, J. 2005 "The Interaction between the EU Emissions Trading Scheme and National Energy Policies: A General Framework" Climate Policy 5, 7996.

Smith, S. 1999. "The Compatibility of Tradable Permits with Other Environmental Policy Instruments", in Implementing Domestic Tradable Permits for Environmental Protection, Paris, OECD.

Sorrell, S. and J. Sijm. 2003. "Carbon trading in the policy mix" Oxford Review of Economic Policy, 19(3) pp. 420-437.

Tietenberg, Thomas. 1990. "Economic Instruments for Environmental Regulation" Oxford Review of Economic Policy 6(1): 17-33.

Unger, T., and E.O. Ahlgren. 2005."Impacts of a common green certificate market on electricity and CO2 emission markets in the Nordic countries" Energy Policy 33:2152-2163. 
Walls, Margaret and Palmer, Karen. 2001. "Upstream Pollution, Downstream Waste Disposal, and the Design of Comprehensive Environmental Policies" Journal of Environmental Economics and Management 41(1): 94-108.

Weitzman, Martin. 1974. "Prices vs. Quantities" Review of Economic Studies. 41(4): 477-491. 
Figure 1

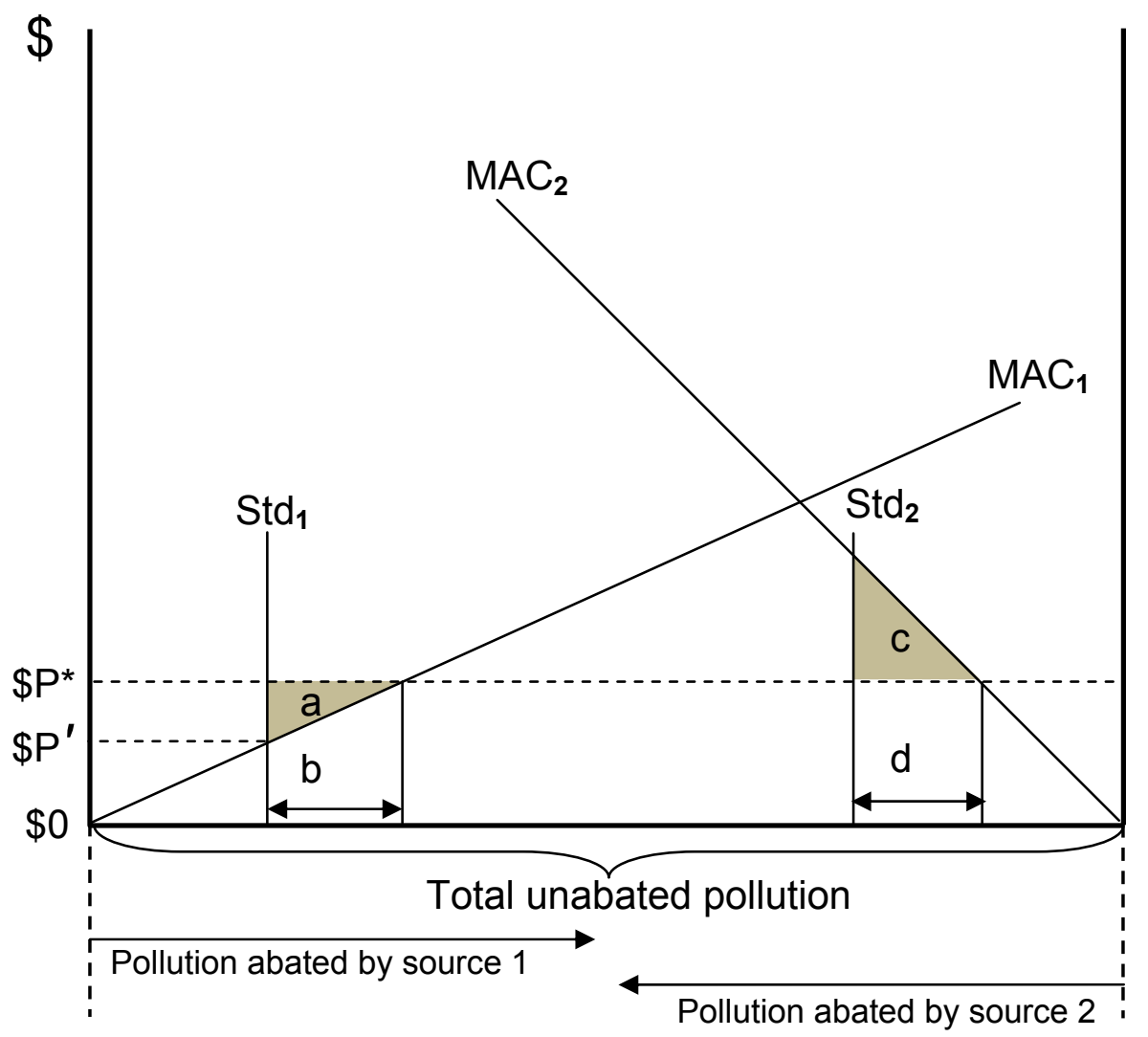

